\title{
Financial Viability of Hatchery Rearing of Oreochromis niloti- cus at Dera District, Amhara Region, Ethiopia
}

\author{
Erkie Asmare* \\ Bahir Dar Fisheries and Other Aquatic Life Research Center, Bahir Dar, Ethiopia
}

"Corresponding author: Erkie Asmare, Bahir Dar Fisheries and Other Aquatic Life Research Center, Bahir Dar, Ethiopia. Tel: +251918271253; Email: dawitasmare2015@gmail.com

Citation: Asmare E (2017) Financial Viability of Hatchery Rearing of Oreochromis niloticus at Dera District, Amhara Region, Ethiopia. J Fish Aqua Dev: JFAD-107. DOI:10.29011/JFAD-107/100007

Received Date: 14 March, 2017; Accepted Date: May 2, 2017; Published Date: May 10, 2017

\begin{abstract}
Hatchery rearing based aquaculture development in Amhara region has been among the less attended sector of the economy for a long time. The study was designed to: quantify costs and benefits associated with the hatchery rearing process; and recommend the means that minimize costs and maximize the benefits. The study was conducted at the ponds in Momoshta and Wan aye kebeles of the Dera district, starting from October 2014 to June 2016. The study revealed that hatchery rearing is a profitable business with a Net Present Value (NPV) and Internal Rate of Return (IRR) equals to 60,137 and $43 \%$ respectively. Moreover, the calculated payback period for the total capital invested is 2.1 years. Based on all the financial criteria, hatchery rearing is viable and has a remarkable profit for smallholder farmers. Besides, hatchery rearing is the only seed for aquaculture development, this makes hatchery rearing a lucrative business for subsistence small holder farmers. However, NPV is extremely sensitive to the change in price and amount of feed required. Even with pessimistic assumptions hatchery rearing remain financially viable with a meaningful profit.
\end{abstract}

Keywords: Financially Viable; Fingerling Source; Net Present Value; Sensitivity Analysis

\section{Introduction}

Ethiopia is a land-locked country which has approximately $7400 \mathrm{Km} 2$ surface area of water body and $7185 \mathrm{Km}$ long river network [1]. However, fish production from these water bodies even used to their full potential couldn't satisfy the increasing fish demand. Capture fisheries fall short of world demand, annual consumption of seafood has been rising, doubling in three decades [2-4] has estimated aggregated demand growth for fish in Ethiopia to be $44 \%$ over ten years; while the supply from capture fisheries is lagging behind the demand

for fish which is growing in Ethiopia [5]. Early investigations by FAO as cited in [6], have indicated that the national per capita fish consumption is $0.21 \mathrm{~kg} /$ person/yr and in fish producing areas of Ethiopia is estimated at $8.5 \mathrm{~kg} / \mathrm{person} / \mathrm{yr}$. Catches from natural ecosystem has declined over time due to increased anthropogenic activities, climate change and illegal, unreported and unregulated fishing [1]. One of the ways to bridge the gap between the reduced fish supply and increased world fish food demand is through aquaculture [7]. Therefore, the current increase in the market demand for fish protein in Ethiopia can be met only when the capture fishery is supplemented by culture fishery $[8,9]$.

Aquaculture contributes to the livelihoods of the poor through improved food supply, employment, and income generation. And it can also provide a viable socio-economic alternative to capture fisheries [10]. Aquaculture is carried out not only for increasing the availability of fish for food but also to conserve the natural stock and thereby protect the biodiversity [11]. Aquaculture can serve as one of the best alternatives for the over-exploited natural aquatic resources. Therefore, it can help to reduce pressure and maintain the ecological balance of the natural ecosystems [12].

Despite of having favorable physical and hydrographic conditions (suitable geographic relief, rich soil quality, good mean annual rainfall, and sufficient freshwater availability), the aquaculture production is negligible in Ethiopia. In addition to this, aquaculture production has more potential than in actual practice, despite the fact that the country's environmental and socio-economic conditions support its development [13]. More specifically, 
aquaculture development in Amhara region has been among the less attended sector of the economy for a longer time, with limited budget and manpower allocated to it.

Expansion of pond farming in Dera district is hindered by the shortage of fingerlings, lack of affordable quality feed, convenient transportation facility, inadequate and inappropriate technical advice/ information, and use of inappropriate production systems. Moreover, hatchery rearing for the development of fish farming, especially among smallholder farmers is not known yet. To make aquaculture more effective, hatchery rearing has an important role to solve the fingerling scarcity at a time of demand. Therefore, this study was aimed to: quantify costs and benefits associated with the hatchery rearing process; and recommend the means that reduce costs and maximize the benefits.

\section{Materials and Methods}

\section{Description of the Study Area and Site Selection}

The study was conducted in the district of Dera in the South Gondar zone of Amhara regional state (Figure 1).

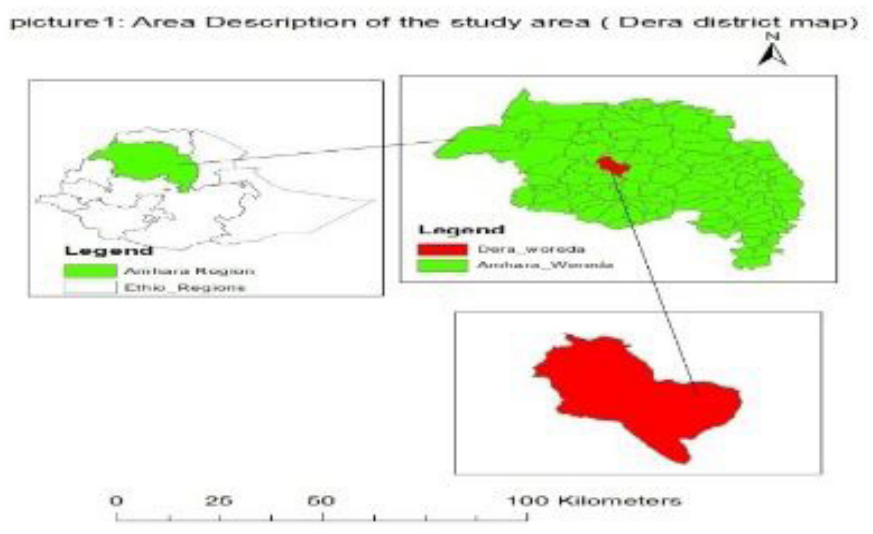

Figure 1: Map of the study area.

Dera district is bordered on the South by the Abay River, which separates it from the West Gojjam zone, on the West by Lake Tana, on the North by Fogera, on the Northeast by East Estie, and on the East by West Estie. The study area is situated $48 \mathrm{~km}$ far from the Southeast of Bahir Dar Town. The rainfall is characterized by a bimodal distribution with the major rainy season occurring from June to August (locally called "Kermit") and the short rainy season extends from March to May ("Belg"). The annual average rainfall varies between 1000 and $1500 \mathrm{~mm}$, while the annual average temperature ranges from 13 to $27^{\circ} \mathrm{C}$ [14].

The district is known for its ample water resource and potential for horticultural crop cultivation either by irrigation or by water harvesting ponds. Following the occurrence of recurrent drought, water harvesting through preparing ponds were mainly practiced starting from the previous Derg regime. The district is also conducive for aquaculture in its physical and hydrographic conditions (suitable geographic relief, rich soil quality, good mean annual rainfall, and sufficient freshwater availability). However, integration of this water harvesting system with aquaculture to gain multiple benefits has been neglected.

\section{Pond Characteristics and Stocking Procedures}

The study was conducted at the ponds located in Momoshta, Wan aye, and Korata kebele of Dera district starting from October 2014 to June 2016. During site selection, water resource availability, characteristics of the soil, climatic condition, suitability of the land including its slope were critically considered. The three constructed ponds have an average of $340 \mathrm{~m} 2$ size and 1.5 meters' depth sealed with black polyethylene geo-membranes in the bottom. (Figure 2)
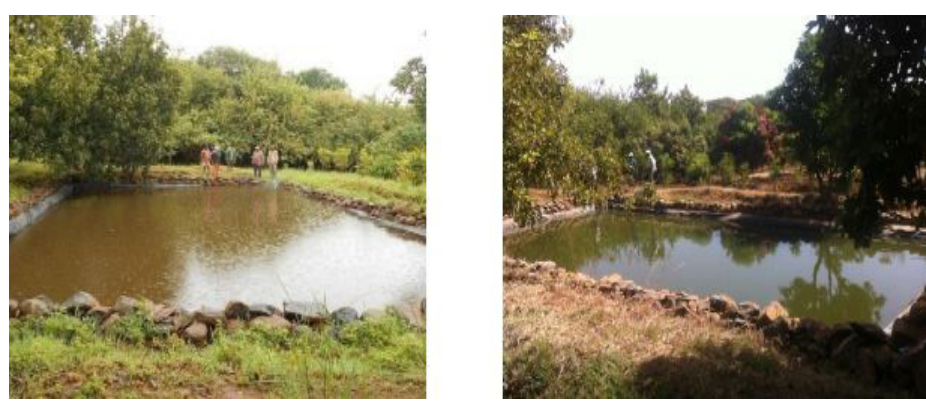

Figure 2: Constructed hatchery rearing pond at Momoshta nursery site.

A study by [11] reported manuring in earthen ponds is found to be the efficient tool for maintaining water quality due to higher assimilation capacity and plankton population, which enhances fish growth and benefit the farmer economically to reduce $50 \%$ cost of inorganic fertilizer and supplementary feed. Therefore, ponds were fertilized before stocking with cow dung for fourteen days until the ponds' water become productive in planktons. Oreochromis niloticus fingerlings with average weight of 30 to $40 \mathrm{~g}$ and at stocking density of 2 fingerlings per meter square were introduced into the ponds. The most commonly feed used were a combination of wheat bran, noun cake and brewery wastes in at the rate of $3-5 \%$ of their body weight mostly on a daily basis. Left over after human consumption, cow dung, and poultry excreta were also used as a fish feed.

\section{Data Collection}

The costs incurred in land clearing, pond construction, purchase of fingerlings, fertilizing, harvesting, maintaining, and the benefit from the sale of fingerlings and market sized fish were quantified using market price. In addition, perception of the stakeholders on the technology was collected through focus group discussion and in the field day.

\section{Data Analysis}

Quantitative and qualitative methods of data analysis were used. Financial analysis was carried out to determine whether 
hatchery rearing activity should be under taken or not and to quantify the profitability of hatchery rearing. To quantify and compare the lifetime costs and benefits (both tangible and intangible) of hatchery rearing by presenting as a single number, Net Present Value (NPV) was employed

$\mathrm{NPV}=\sum_{\mathrm{t}=0}^{\mathrm{n}} \frac{(\mathrm{Bt}-\mathrm{Ct})}{(1+\mathrm{r}) \mathrm{t}} \mathrm{NPV}=\sum_{\mathrm{t}=0}^{\mathrm{n}} \frac{(\mathrm{Bt}-\mathrm{Ct})}{(1+\mathrm{r}) \mathrm{t}}$

Where, $\mathrm{n}$ is the number of years for which the project will operate, $r$ is the proportionate financial or economic discount rate; $\mathrm{Bt}$ and $\mathrm{Ct}$ are the project benefits and costs at period $\mathrm{t}$ respectively. In addition, Internal Rate of Return (IRR) that makes NPV equal to zero was calculated by using a formula:

$\operatorname{IRR}=\frac{\left(B_{0}-C_{0}\right)}{(1+r) 0}+\left(\frac{(B 1-C 1)}{(1+r) 1}\right)+\frac{\left(B 2-C_{2}\right)}{(1+r) 2}+\ldots+\frac{(B t-C t)}{(1+r) t}=0$
$I R R=\frac{(B 0-C 0)}{(1+r) 0}+\left(\frac{(B 1-C 1)}{(1+r) 1}\right)+\frac{(B 2-C 2)}{(1+r) 2}+\ldots+\frac{(B t-C t)}{(1+r) t}=0 \ldots$ (ii)

Where, IRR is the discount rate that makes the present value just equal to zero. The viability of the hatchery rearing was also tested using the Benefit Cost Ratio (BCR) criterion. The formula used for the Benefit - Cost Ratio was as follows:

$\mathrm{BCR}=\frac{\sum_{\mathrm{t}=0}^{\mathrm{n}(1+\mathrm{s}) \mathrm{r}) \mathrm{t}}}{\sum_{\mathrm{t}=0}^{\mathrm{n}} \frac{(\mathrm{Ct})}{(1+\mathrm{r}) \mathrm{t}}} \mathrm{BCR}=\frac{\sum_{\mathrm{t}=0}^{\mathrm{n}} \frac{(\mathrm{Bt})}{(1+\mathrm{r}) \mathrm{t}}}{\sum_{\mathrm{t}=0}^{\mathrm{n}} \frac{(\mathrm{Ct})}{(1+\mathrm{r}) \mathrm{t}}}$

Moreover, Return On Investment (ROI) was calculated to know the percentage returns from operating hatchery rearing. jt86496i05

$$
\begin{aligned}
& \text { ROI }=\frac{\text { Discounted benefit }- \text { Discounted cost }}{\text { Discounted cost }} \\
& \text { ROI }=\frac{\text { Discounted benefit }- \text { Discounted cost }}{\text { Discounted cost }} * 100 .
\end{aligned}
$$

To know how much value, we receive per each ETB (Ethiopian Birr) invested, Profitability Index (PI) have been calculated by dividing the present value of future cash flows by the initial investment required for the hatchery rearing.

$$
\begin{aligned}
& \text { PI }=\frac{\text { Present Value of Future Cash Flows }}{\text { Initial Investment Required }} \\
& \text { PI }=\frac{\text { Present Value of Future Cash Flows }}{\text { Initial Investment Required }} .
\end{aligned}
$$

\begin{tabular}{|c|c|c|c|}
\hline \multicolumn{4}{|c|}{ Decision Rule } \\
\hline $\begin{array}{c}\text { Decision mak- } \\
\text { ing criteria }\end{array}$ & Accept & Reject & Indifferent \\
\hline $\mathrm{NPV}$ & $\mathrm{NPV}>0$ & $\mathrm{NPV}<\mathrm{O}$ & $\mathrm{NPV}=0$ \\
\hline $\mathrm{IRR}$ & $\mathrm{IRR}>\mathrm{r}$ & $\mathrm{IRR}<\mathrm{r}$ & $\mathrm{IRR}=\mathrm{r}$ \\
\hline $\mathrm{BCR}$ & $\mathrm{BCR}>1$ & $\mathrm{BCR}<1$ & $\mathrm{BCR}=1$ \\
\hline $\mathrm{PI}$ & $\mathrm{PI}>1$ & $\mathrm{PI}<1$ & $\mathrm{PI}=1$ \\
\hline $\mathrm{ROI}$ & $\mathrm{ROI}>0$ & $\mathrm{ROI}<0$ & $\mathrm{ROI}=0$ \\
\hline
\end{tabular}

Table 1: Decision Making Criteria.

Sensitivity analysis: NPVs are estimated based on the calculations of future costs and benefits that are not, and cannot, be known with certainty. To reduce this uncertainty, a detailed sensitivity analysis was carried out to test the net present value using acceptable 'Pessimistic' and 'Optimistic' assumptions about key variables that determine costs and benefits. The sensitiveness of the NPV and other decision-making criteria (Table 1) for a unit change in selected variables (Table 2) were calculated by using Sensitivity Index (SI) as used by [15].

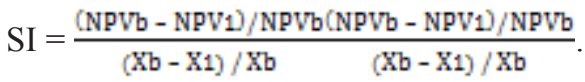

Where: $\mathrm{SI}$ is the sensitivity index $\mathrm{Xb}$-value of variable in the base case X1-value of the variable in the sensitivity test. NPVb is value of NPV in the base case, while NPV1 is value of the variable in the sensitivity test.

\begin{tabular}{|c|c|}
\hline Assumptions & $\begin{array}{c}\text { Percentage Incre- } \\
\text { ment/ Decrement }\end{array}$ \\
\hline Sensitivity to Increase in Costs & $10 \%$ \\
\hline Labour cost increased by & $10 \%$ \\
\hline Feed required increased by & $10 \%$ \\
\hline Yield declined by & $10 \%$ \\
\hline Price decreased by & $10 \%$ \\
\hline Both changed at once* & $10 \%$ \\
\hline Sensitivity to increase in yield and price of \\
harvest & $10 \%$ \\
\hline Yield increased & $10 \%$ \\
\hline Price of catch increased & Both changed at once** \\
\hline $\begin{array}{c}\text { * Both labour cost, amount of feed required become increased by } 10 \% \\
\text { and the yield declined by } 10 \% \text {. }{ }^{*} \text { When both catch and price of harvest }\end{array}$ \\
\hline \multicolumn{2}{|c|}{ increased by $10 \%$. } \\
\hline
\end{tabular}

Table 2: Sensitivity to analysis under different assumptions. 


\section{Results and Discussion}

\section{Costs and Benefits of Hatchery Rearing}

During the study, the costs of hatchery rearing have been categorized under fixed costs and variable (operational) costs. The main items considered as fixed or initial investment cost were geomembrane, net, construction, and cost of renting land, fence and constructing equipment which values ETB16545. From the total initial investment costs, $47.5 \%$ of the costs are from geo-membrane. Regarding the operational costs labour, seed or fingerlings, feed, maintenance and maintenance related inputs were identified with their expected costs. The yearly calculated costs of operation were ETB8040 at the first year within which pump rent and feed costs take their large share (Table 3 ).

\begin{tabular}{|c|c|}
\hline Fixed Costs & Costs in ETB \\
\hline Geo-membrane & 7865 \\
\hline Construction & 4900 \\
\hline Fishing net & 1500 \\
\hline Opportunity costs of land & 1480 \\
\hline PVC and digging equipment's & 800 \\
\hline Total fixed cost & 16545 \\
\hline Variable inputs & Annual cost in ETB \\
\hline Labour for fertilizing and feeding & 304.1667 \\
\hline Fingerlings & 394 \\
\hline Glue for maintenance & 200 \\
\hline Feed & 1800 \\
\hline Fuel to fill the pond & 160 \\
\hline Pump rent cost per year & 2400 \\
\hline Fencing the pond & 1000 \\
\hline Maintenance* & 0 \\
\hline Disinfectant & 120 \\
\hline $\begin{array}{l}\text { Labour for stocking and harvest- } \\
\text { ing }\end{array}$ & 507.8571 \\
\hline Fish died during stocking & 39.4 \\
\hline Fish died during harvest & 800 \\
\hline Labour for drain in and out & 315 \\
\hline TVC per $340 \mathrm{~m} 2$ & 8040.42 \\
\hline \multicolumn{2}{|c|}{$\begin{array}{l}\text { *Note: Maintenance costs are consisting of costs for maintenance of } \\
\text { fishing nets, black polyethylene geo-membrane and fence. }\end{array}$} \\
\hline
\end{tabular}

Table 3: Initial investment cost and annual operational costs at the first year.

Qualitative data collected during the field day and from focus group discussion has shown that hatchery rearing has numerous benefits, besides its direct benefits. Among the indirect benefits, pond based hatchery rearing help to: conserve the over exploited fish at a private level, reduce pressure in capture fisheries, improve the values of the site, assist the re-establishment of trees and other vegetables around the ponds, good source of organic fertilizer from pond water and nutrient recycles when it integrates with agricultural activities.

Hatchery rearing plays a significant role as a means of income generation (net benefit of ETB 3057 was gained at first year), source of seed for aquaculture, and food source (matured male fish). It has also served as a water bank (water hole) by facilitating water management and water conservation for supplementary irrigation at smallholder farmer level. The net benefit from the hatchery rearing increased at an increasing rate up to the second year and then starts to increase at decreasing rate up to the third year (Figure 3).

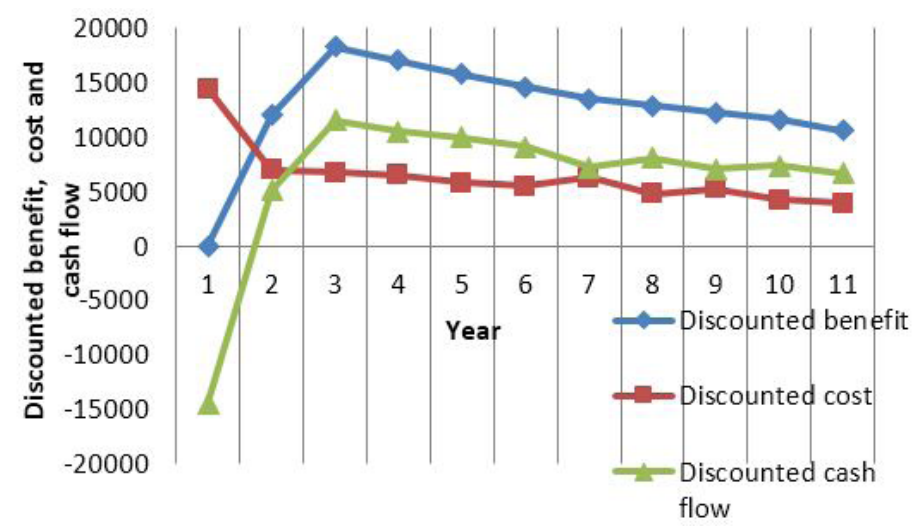

Figure 3: Discounted benefit, cost and cash flow.

This increment in yield might have a strong association with: increase in pond and water productivity; the parent stock becomes mature with high fertility or fecundity rate; fishes adapt the new environmental condition including the breeding grounds; and stocks in the pond become increased. Generally, hatchery rearing is economically and environmentally sound with a remarkable profit (NPV= 60137 per $340 \mathrm{~m} 2$ pond) (Table 4).

Even though the discounted benefits are above the discounted costs, the discounted benefits of the investment start to decrease after the third year. Based on the findings of the study, discounted return might start to decline as the pond becomes old and needs intensive management. Hence, the benefits started to decrease due to increase in labour cost, feed requirement and its price and other variable costs such as, maintenance costs for fishing nets, black polyethylene geo-membrane, fence and other equipment's. When the fish population of the pond is beyond the ponds' carrying capacity, there would be high competition for feed, oxygen, and breeding ground or place. These congestions and competition highly affect both growth and reproductive performance negatively. 
Citation: Asmare E (2017) Financial Viability of Hatchery Rearing of Oreochromis niloticus at Dera District, Amhara Region, Ethiopia. J Fish Aqua Dev: JFAD-107.

\begin{tabular}{|c|c|c|c|}
\hline Year & Cash flow & $\begin{array}{c}\text { @ } 12.5 \% \text { discounted rate } \\
\text { Discounted } \\
\text { Flow Discount factor }\end{array}$ & cash \\
\hline 0 & -16545 & 1 & -16545 \\
\hline 1 & 3057.543 & 0.8889 & 2717.82 \\
\hline 2 & 14131.41 & 0.7901 & 11165.56 \\
\hline 3 & 12738.92 & 0.7023 & 8946.95 \\
\hline 4 & 15487.46 & 0.6243 & 9668.75 \\
\hline 5 & 15860.38 & 0.5549 & 8801.38 \\
\hline 6 & 14092.11 & 0.4933 & 6951.22 \\
\hline 7 & 17952.94 & 0.4385 & 7871.69 \\
\hline 8 & 17589.66 & 0.3897 & 6855.47 \\
\hline 9 & 20765.64 & 0.3464 & 7194.04 \\
\hline 10 & 21137.93 & 0.3079 & 6509.34 \\
\hline & & NPV & 60137 \\
\hline & & IRR & 0.43 \\
\hline & & IP & 3.63 \\
\hline & & BCR & 1.82 \\
\hline & & PBP & 2.11 \\
\hline & & ROI & 81.96 \\
\hline
\end{tabular}

Table 4: Financial Cash Flow.

NPV is an indicator of how much value an investment in hatchery rearing accrues benefit to the smallholder farmers. The NPV equals to 60,137 which is positive enough, this indicates that the estimated earnings generated from hatchery rearing investment exceed the anticipated costs. In addition, hatchery rearing is only worth when percentage return to the money invested in it is greater than the interest rate paid to borrow the money. Hence, the IRR that can be compared with the current interest rate for borrowing the capital required is greater than the discount rate $(\mathrm{r}=12.5 \%)$. This shows that, the money invested in hatchery rearing generates exactly $43 \%$ return. Based on the two criteria, investing in hatchery rearing would generate enough income to repay if it was started on the loan and still provide profits.

The other financial analysis tools were also used to estimate the viability of hatchery rearing at smallholder farmer level. A benefit-cost ratio equals is 1.82 which means smallholder farmers can expect ETB1.82 benefits for every 1ETB investment. In the hatchery rearing process, a $\mathrm{BCR}$ greater than 1 means the benefits are more important than the costs and the investment should be considered. The Return on Investment (ROI) result, 81.96\% shows, the investment (i.e., the cost) in hatchery rearing can generate a return (i.e., net benefit) that exceed the cost of the investment by $81.96 \%$.

Based on the profitability index rule, shows each birr invested in fixed input in hatchery rearing yields ETB3.63 return. This means that the total cost of the investment was recovered in addition to some profits left over. The discounted payback period

that indicates the amount of time required to earn back initial investment costs is 2.1 years. Based on these criteria, investment in hatchery rearing can earn back the initial investment costs within two years and one month. Based on all the financial criteria, hatchery rearing is viable and has a remarkable profit for smallholder farmers.

\section{Sensitivity Analysis}

The viability of hatchery rearing is based on IRR and NPV criteria. However, the net present values are estimated based on estimates of future costs and benefits that are known certainly. Due to the presence of uncertainties in the quantification of costs and benefits using decision making criteria such as; NPV, BCR, and IRR may not be comprehensive. Making sensitivity analysis using acceptable 'Pessimistic' and 'Optimistic' assumptions about key variables that determine costs and benefits is essential. It is also useful to identify the sensitiveness of NPV with change in variables like, price, amount caught, labour and fish feed. (Table 5)

\begin{tabular}{|c|c|c|c|c|c|}
\hline Assumptions & \multicolumn{5}{|c|}{ Decision Tools } \\
\hline $\begin{array}{c}\text { Sensitivity to in- } \\
\text { crease in costs }\end{array}$ & NPV & IRR & BCR & PBP & SI \\
\hline $\begin{array}{c}\text { Wage rate increased } \\
\text { by } 10 \%\end{array}$ & 59400.21 & $42 \%$ & 1.8 & 2.12 & $12.3 \%$ \\
\hline $\begin{array}{c}\text { Feed price increased } \\
\text { by } 10 \%\end{array}$ & 58688.09 & $42 \%$ & 1.78 & 2.14 & $24.1 \%$ \\
\hline $\begin{array}{c}\text { Yield declined by } \\
10 \%\end{array}$ & 49733.37 & $37 \%$ & 1.7 & 2.33 & $173 \%$ \\
\hline $\begin{array}{c}\text { Price decreased by } \\
10 \%\end{array}$ & 49873.76 & $37 \%$ & 1.7 & 2.33 & $170.7 \%$ \\
\hline Sensitivity to increase in yield and price of harvest \\
\hline $\begin{array}{c}\text { Yield increased by } \\
10 \%\end{array}$ & 70393.53 & $49 \%$ & 1.94 & 1.94 & $170.5 \%$ \\
\hline $\begin{array}{c}\text { Price of catch in- } \\
\text { creased by } 10 \%\end{array}$ & 70400.66 & $49 \%$ & 1.9 & 1.9 & $170.70 \%$ \\
\hline $\begin{array}{c}\text { Both changed at } \\
\text { once** }\end{array}$ & 81574.42 & $55 \%$ & 2.06 & 1.8 & - \\
\hline
\end{tabular}

* When labour cost, amount of feed required become increased by $10 \%$ and the yield declined by $10 \%$. ${ }^{* *}$ When both catch and price of harvest increased by $10 \%$ as the sensitivity analysis shows, the value of NPV is still positive with every change in the variable inputs. The sensitiveness of NPV for a unit change in selected variables using Sensitivity Index (SI) showed, NPV is extremely sensitive to change in price of fingerlings and table sized fish. In addition, NPV is found to be more sensitive to amount of feed required. The ratio of the percentage of change in NPV to the percentage of change in price is greater than one or $100 \%$. This means that for every slight change in the price for fingerlings and market sized fish, the net present value changes extremely. Even though they showed certain sensitivity, the variables do not substantially affect the profitability or net present value of the hatchery rearing operation. Therefore, we can conclude that even with pessimistic assumptions hatchery rearing remain financially viable with remarkable profit.

Table 5: Sensitivity Analysis. 


\section{Conclusions and Recommendations}

The study area has the potential to develop aquaculture that can play an important role in ensuring food security and support for livelihood improvement when practiced at large scale. To make aquaculture more effective, hatchery rearing play substantial role by solving the problem of fingerling scarcity at a time of demand. Hatchery rearing is also the only means which provide seed for aquaculture development, this makes hatchery rearing a rewarding business for subsistence small holder farmers. It also serves as a means of livelihood diversification and water bank (water hole) by facilitating water management and water conservation for supplementary irrigation at smallholder farmer level. For every slight change in the price for fingerlings and fish feed the net present value changes exceedingly, but the NPV still remains positive. We can conclude that, hatchery rearing is viable and have a remarkable profit for farmers. If the hatchery rearing is expected to play its role, the following issue requires due attention:

- The initial costs of pond construction may not be simply affordable for subsistence smallholder farmers. Therefore, giving pond construction inputs like geo-membrane and other equipment's either as an incentive or on a loan basis.

- Use locally available feed staffs such as, poultry excreta, animal manure, wastes after human consumption and others to cutoff feed costs.

- Transfer fingerlings to fish production ponds to reduce feed competition and over population.

- The profit from hatchery rearing is too sensitive to price change, therefore, promotion, market linkage and stabilizing fingerling price will attract farmers and guarantee its future sustainability.

- The interest in investing in hatchery rearing is based on demand for fingerlings. Therefore, expansion of pond fish production will increase fingerlings price and makes hatchery rearing attractive to fingerling suppliers.

\section{References}

1. Erkie A, Sewmehon D, Dereje T, Mihret E (2016) Impact of climate change and anthropogenic activities on livelihood of fishing community around Lake Tana, Ethiopia. Journal of EC Cronicon Agriculture 3: 548-557.

2. Neori A, Chopin T, Troell M, Buschmann AH, Kraemer GP, et al. (2004) Integrated aquaculture : rationale, evolution and state of the art emphasizing seaweed biofiltration in modern mariculture. Aquaculture 231: 361-391.
3. FAO (2000) The state of world fisheries and aquaculture. Fisheries and Aquaculture Department.

4. Gordon A, Sewmehon D, Melaku T (2007) Marketing systems for fish from Lake Tana, Ethiopia: Opportunities for marketing and livelihoods (IPMS (Improving Productivity and Market Success) of Ethiopian Farmers Project Working Paper 2) Nairobi Kenya.

5. Rothuis A, van Duijn AP, Eshete D, Kamstra A, van der Pij W, et al. (2012) Business opportunities for aquaculture in Ethiopia Summary. Den Haag.

6. Hussein A, Alayu Y, Ermias M (2012) Fish Resource Survey in Benishangul-Gumuz Regional State based on Fish Resource Survey in Benishangul-Gumuz Regional State. In The Fourth Annual Conference of the Ethiopian Fisheries and Aquatic Sciences Association (EFASA)"The role of aquatic resources for food security in Ethiopia" 219: 245.

7. Olaoye OJ, Adegbite DA, Oluwala EO, Vaughan IO, Odebiyi CO, et al. (2014) Comparative Evaluation of Economic Benefits of Earthen Fish Ponds and Concrete Tanks in Aquaculture Enterprises in Oyo State , Nigeria. Croatian Journal of Fisheries 72: 107-117.

8. Ashagrie G, Abebe G, Seyoum M (2008) Effect of stocking density on the growth performance and yield of Nile tilapia Oreochromis niloticus ( $\mathrm{L}, 1758$ ) in a cage culture system in Lake Kuriftu, Aquaculture Research 39: 1450-1460.

9. Berihun T, Goraw G (2010) Integrating aquaculture with traditional farming system: socioeconomic assessment in the Amhara Region, Ethiopia. Ecohydrology\&Hydrobiology 10: 223-230.

10. Agbebi FO (2011) Impact of Fish Farming on Poverty Alleviation in Ekiti-State. International Journal of Science and Nature 2: 456-460.

11. Dereje D, Devi LP, Sreenivasa V, Abebe G (2015) The growth performance of Nile tilapia in earthen ponds located at different altitudes of Toke Kutaye Woreda, Ethiopia. International Journal of Aquaculture 5: 1-7.

12. Kassahun A (2012) Utilization of locally available feedstuffs for smallscale aquaculture production in Ethiopia. Natural Resources and Applied Life Sciences.

13. FAO (2014) Fishery and Aquaculture Country Profiles: The Federal Democratic Republic of Ethiopia. FAO Fisheries and Aquaculture Department. Rome.

14. Dagninet A, Wolde M, Beyene B (2017) Willingness and Participation of Local Communities to Manage Communal Grazing Lands in the Lake Tana Biosphere, Ethiopia. Society \& Natural Resources: 1-16.

15. Iloiu M, Csiminga D (2009) Project Risk Evaluation Methods - Sensitivity Analysis. Annals of the University of Petroşani Economics 9: 33-38. 